\section{'Orange Hot' Anthurium}

\author{
R.J. Henny, D.J. Norman, and J. Chen \\ University of Florida, Institute of Food and Agricultural Science, Mid-Florida \\ Research and Education Center, 2725 Binion Road, Apopka, FL 32703
}

Additional index words. Anthurium andraeanum, Araceae, floricultural production, foliage plant, plant breeding

Anthurium andraeanum Linden (Araceae Juss.) is grown traditionally for cut flowers because of its large and showy red, orange, pink, or white spathes. The large leaves and long petioles and peduncles generally preclude use as pot plants. Recently, newly developed interspecific hybrids, such as 'Lady Jane' (Kamemoto and Kuehnle, 1996), 'Southern Blush' (Henny et al., 1988) and 'Red Hot' (Henny and Norman, 1999) are being grown as flowering pot plants because their smaller size is suitable for pot production and they are highly floriferous.

\section{Origin}

'Orange Hot' is a sport found among a large greenhouse population of tissue-cultured plants of 'Red Hot'. The plant displays numerous showy light orange spathes and spadices and, like its parent 'Red Hot', possesses a compact, freely branching growth habit that makes it a desirable commercial cultivar. 'Orange Hot' has been propagated in tissue culture. Its orange spathe and spadix color is stable, and plants maintain the other desirable traits found in 'Red Hot'. Therefore 'Orange Hot' has been selected for release through the foliage plant breeding program of the FloridaAgricultural Experiment Station at the Mid-Florida Research and Education Center (MREC).

\section{Description}

The following characteristics are typical for a one-year-old 'Orange Hot' plant grown in a 1.6- $\mathrm{L}$ pot. Mature leaves are lanceolate, 18 to $20 \mathrm{~cm}$ in length and 9 to $11 \mathrm{~cm}$ in width at the widest part. The upper leaf surface is dark green [Royal Horticultural Society (RHS) 146B-C, (Royal Horticultural Society, 1995)], whereas the leaf underside is a lighter green (RHS 139A). Petioles are a uniform yellowgreen (RHS 146B-C). 'Orange Hot' produces spathes that are 6 to $7 \mathrm{~cm}$ long and 4 to $5 \mathrm{~cm}$ wide. They are held on petioles that are 25 to $35 \mathrm{~cm}$ long, which locates the inflorescences above the leaf canopy where they are easily seen. New spathes unfurl light salmon orange in color (RHS 39B-C), and gradually fade over a period of 2 to 3 weeks to a lighter orange color (RHS 36B-C). The spadix at anthesis is light orange (RHS 38A) at the base and increases in intensity to RHS 39A-B at the

Received for publication 11 Dec. 2001. Accepted for publication 8 May 2002. Florida Agricultural Experiment Station Journal Series No. R-08887. apex. In older flowers the spadix becomes a uniform lighter orange (RHS 37D). Peduncles are yellow-green (RHS 152A-B) at the base and darken to greyed-orange (RHS 172D) near the spathe.

\section{Performance}

Growth characteristics of 'Orange Hot' were determined using 30 liners that were 20 weeks from tissue culture and well-rooted in $25-\mathrm{mm}$ cell trays. Liners were potted into 1.6-L plastic pots containing a substrate of 3 Canadian peat : 2 perlite (by volume). The substrate was amended with $0.9 \mathrm{~kg} \cdot \mathrm{m}^{-3}$ of Micromax, a micronutrient source (Sierra Chemical Co., Milpitas, Calif.) and $4.1 \mathrm{~kg} \cdot \mathrm{m}^{-3}$ dolomite. Plants were grown in a shaded greenhouse with a maximum irradiance of
Ns, *Nonsignificant or significant at 0.05 .
$125 \mu \mathrm{mol} \cdot \mathrm{s}^{-1} \cdot \mathrm{m}^{-2}$, natural photoperiod and a temperature range of 15 to $34^{\circ} \mathrm{C}$. Ten plants were grown for 7 months from 14 Dec. 1999 to 16 June 2000 , at each of three fertilizer levels equivalent to 34,68 , and $101 \mathrm{~g} \cdot \mathrm{m}^{-2}$ of $\mathrm{N} /$ year. Fertilizer levels were derived from a $3 \mathrm{~N}-1 \mathrm{P}-2 \mathrm{~K}$ ratio applied as a liquid at $100 \mathrm{~mL} /$ pot per week. The experiment was setup in a completely randomized design. Data recorded at termination of the study included canopy height and width, length and width of largest leaf, number of open flowers present at termination and a rating for visual quality where $1=$ dead, $3=$ acceptable, and $5=$ excellent quality. Data were analyzed using analysis of variance procedures of the SAS program version (SAS Institute, Cary, N.C.). Parameters with means showing significant differences were subjected to regression analysis.

'Orange Hot' reached marketable size in 7 months. Fertilizer level did not significantly affect any of the variables measured except canopy width which increased linearly as fertilizer level increased (Table 1). Mature plants were more than twice as wide as they were tall. Both primary and secondary shoots produced inflorescences resulting in mean open flower counts of four to five per plant. Plant quality was good to excellent overall with slightly higher ratings for plants at the higher nutritional levels.

Table 1. Final canopy height and width, length and width of largest leaf, visual quality and total number of open flowers at termination produced by 'Orange Hot' Anthurium grown in 1.6-L pots for 7 months from 14 Dec. 1999 until 16 June 2000.

\begin{tabular}{lccccccc}
\hline Fertilizer (N) & \multicolumn{2}{c}{ Canopy } & & \multicolumn{2}{c}{ Leaf } & \multicolumn{2}{c}{ Total open } \\
$\begin{array}{l}\text { applied per year } \\
\left(\mathrm{g} \cdot \mathrm{m}^{-2}\right)\end{array}$ & $\begin{array}{c}\text { height } \\
(\mathrm{cm})\end{array}$ & $\begin{array}{c}\text { width } \\
(\mathrm{cm})\end{array}$ & & $\begin{array}{c}\text { length } \\
(\mathrm{cm})\end{array}$ & $\begin{array}{c}\text { width } \\
(\mathrm{cm})\end{array}$ & $\begin{array}{c}\text { flowers at } \\
\text { termination }\end{array}$ & $\begin{array}{c}\text { Visual } \\
\text { quality }^{\mathrm{z}}\end{array}$ \\
\hline 34 & 19.8 & 39.2 & & 18.4 & 10.0 & 4.4 & 3.8 \\
68 & 21.3 & 44.5 & & 18.6 & 10.1 & 5.6 & 4.5 \\
101 & 20.2 & 45.0 & & 19.5 & 10.2 & 4.5 & 4.4 \\
Significance & $\mathrm{NS}$ & $\mathrm{L}^{*}$ & & $\mathrm{NS}$ & $\mathrm{NS}$ & $\mathrm{NS}$ & $\mathrm{NS}$ \\
\hline
\end{tabular}

${ }^{\mathrm{z}}$ Visual rating where $1=$ dead; $3=$ saleable, and $5=$ excellent.

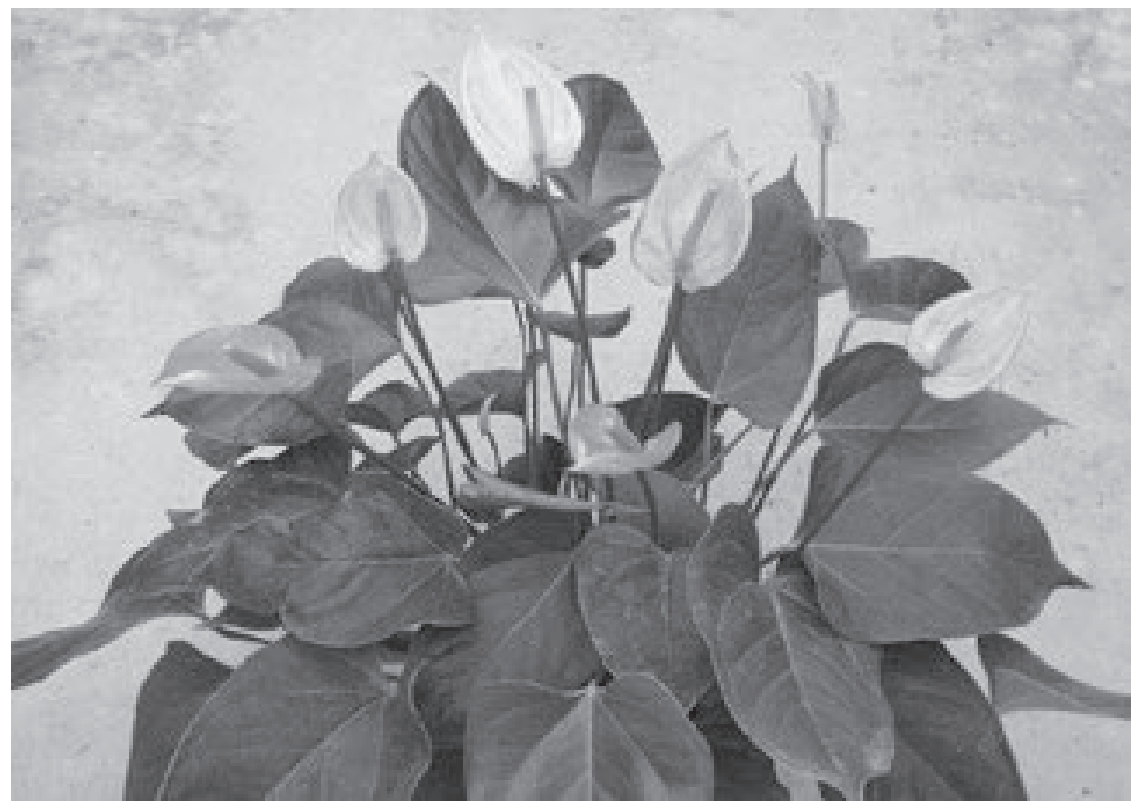

Fig. 1. A mature 7-month-old 'Orange Hot' Anthurium grown in a 1.6-L pot. 


\section{Cultivar \& Germplasm Releases}

\section{Availability}

'Orange Hot' is intended for commercial producers growing finished plants in 1.6- or 3.9-L containers. Plants are being propagated by several Florida tissue culture labs. Inquiries regarding participating laboratories may be obtained by writing the Florida Foundation
Seed Producers, P.O. Box 309, Greenwood, FL 32443. Plants for research purposes may be obtained directly from the author.

\section{Literature Cited}

Henny, R.J., R.T. Poole, and C.A. Conover. 1988. 'Southern Blush' Anthurium. HortScience 23:
922-923.

Henny, R.J. and D.J. Norman. 1999. 'Red Hot' Anthurium. HortScience 34(1):153-154.

Kamemoto, H. and A.R. Kuehnle. 1996. Breeding anthuriums in Hawaii. Univ. Hawaii Press, Honolulu. 132 p.

Royal Horticultural Society. 1995. The Royal Horticultural Society's colour chart. 3rd ed. Royal Hort. Soc., London. 